\title{
The small
}

\section{economies of \\ Latin America \\ and the Caribbean}

\section{Hubert Escaith}

Economic Development

Division,

ECLAC

hescaith@eclac.cl
Population, natural resources and domestic market size have been the traditional components of the equation determining the wealth of nations, according to classical economists. The new lines of research opened up by endogenous growth theories and the results of comparative statistical studies into the factors determining this growth have reawakened interest in the relationships between scale effects, market size and the role of international trade in the economic growth of small economies. At a time of ever-increasing globalization, these economies are being confronted with a number of challenges and opportunities in relation to which their small economic size is generally regarded as a disadvantage. Diseconomies of scale increase their production costs, while their relatively undiversified exports mean they are extremely vulnerable to shocks of external origin. All these factors weigh all the more heavily in that trade has become one of the key factors in economic development, as is demonstrated by the sharp increase in imports and exports as a share of GDP since the second half of the 1980s. The central role played by intraregional trade or the North American market as non-traditional export engines is heightening the importance of price competitiveness, and thus of subsidy or tax exemption programmes to ensure an outlet to these markets. For those small developing countries in the region that suffer relative disadvantages, success would therefore seem to depend on the preferential terms under which they do business with their main developed-world trading partners, namely North America and, for members of the ACP group (the developing countries of Africa, the Caribbean and the Pacific), the European Union. Again, excessive specialization to serve a large regional market (Brazil or the United States) entails risks that merit consideration. 


\section{Main economic characteristics}

There is no universally accepted definition of a small economy. Theoretical analyses often go by whether or not a country is able to influence international pricing. A similar classification, but one which is more useful from the economics point of view, identifies small economies as ones that lack the freedom to take economic policy decisions and have to adjust to the environment created by the economic policies of the major economies. This is the definition used by De Sierra (coord., 1994), in particular. Definitions of this kind are unhelpful in empirical research, however, as they are difficult to observe and measure. For practical reasons, the size of an economy is usually measured by its population, land area or domestic revenue (Damijan, 1997). Gutiérrez (1996) remarks that in Latin America there is a strong correlation among the different indicators that are generally used in the literature on the subject and that a classification by population provides a simple but clearly acceptable way of ranking the region's economies.

If small economies are defined by population (10 million inhabitants or less at the beginning of the 1990s), ${ }^{1}$ most of the Latin American economies are small: all those of the Caribbean except Cuba, those of the Central American isthmus, Bolivia, Ecuador, Paraguay and Uruguay. Many Caribbean islands are very small indeed, containing less than a million inhabitants (and in some cases fewer than 100,000), which heightens their specificity and makes them particularly vulnerable (table 1). Nonetheless, they are all very different in terms of natural resources, per capita income, culture and society, which means that the

The author wishes to express his appreciation to those who participated in the international conference on Europe-Latin America relations and globalization, held in September 2000 by the Centre de Recherche sur l'Amérique Latine et les Caraïbes (Crealc) in Aix-en-Provence, France, and to ECLAC colleagues, particularly Len Ishmael, José Antonio Ocampo and Esteban Pérez, whose comments enriched the previous versions on which this article was based. The opinions expressed herein are those of the author and do not necessarily reflect the views of ECLAC.

${ }^{1}$ This is a very relative criterion. Twenty years earlier, the limit would have been 6.1 million for a similar group of Latin American countries (Real de Azúa, 1997); today it is 13 million, and Cuba would now be considered a small economy (table 1). general conclusions formulated later on need to be kept in perspective if excessive reductionism is to be avoided.

\section{Growth and competitiveness}

The recent literature on economies of scale and endogenous growth in open economies tends to regard a small domestic market as a disadvantage, at least in the early stages of development. The freedom of access to external markets that globalization can provide should in principle help such economies to make up for this constraint. Nonetheless, there is no consensus about the results of trade liberalization and free trade when the trading partners are very unevenly matched in terms of size and development level. Both theory and practice tend to suggest that some countries move on to a slow track and specialize in declining markets, while others take advantage of external markets to develop a dynamic specialization (Ros, 2000).

Among developing countries, "large economies" have per capita income levels considerably higher than those of "small economies"; by contrast, "very small economies" have average per capita incomes comparable to those of the largest economies. The same relationships hold true when growth rates are examined. Seemingly, small economies (but not very small ones) suffer from certain comparative disadvantages (Salvatore, 1997). According to this author, those disadvantages are associated with development level and are generally not found when developed economies are analysed. These results are found to apply, albeit in an attenuated form, in Latin America and the Caribbean. Over the last 20 years, the smallest economies (less than a million inhabitants in 1990) have had a per capita income growth rate at least comparable to, if not higher than, medium-sized or large countries (over 10 million inhabitants). Small economies (between one and 10 million inhabitants) have generally grown more slowly than the other two groups.

Indeed, over a long period, only the very small economies have seen a significant rise in per capita output, while in the medium-sized and large ones the recovery in growth that occurred in the 1990s was barely enough to offset the losses suffered 10 years before as a result of the borrowing policies of the 1970s and the 
Latin America and the Caribbean: Selected demographic and economic indicators

\begin{tabular}{|c|c|c|c|c|c|c|c|}
\hline \multirow[b]{2}{*}{ Period or year } & \multirow{2}{*}{$\begin{array}{c}\text { Population } \\
\text { (thousands } \\
\text { of } \\
\text { inhabitants) }\end{array}$} & \multirow{2}{*}{$\begin{array}{c}\begin{array}{c}\text { Average } \\
\text { annual }\end{array} \\
\text { population } \\
\text { growth rate }\end{array}$} & \multirow{2}{*}{$\begin{array}{c}\begin{array}{c}\text { Population } \\
\text { density }\end{array} \\
\text { (inhabitants/ } \\
\mathrm{km}^{2} \text { ) }\end{array}$} & \multirow{2}{*}{$\begin{array}{c}\text { Per capita } \\
\text { GDP (dollars, } \\
\text { at purchasing } \\
\text { power parity) }\end{array}$} & \multicolumn{2}{|c|}{$\begin{array}{c}\text { Average } \\
\text { annual } \\
\text { GDP growth } \\
\text { rate }\end{array}$} & \multirow{2}{*}{$\begin{array}{c}\begin{array}{c}\text { External } \\
\text { trade } \\
(\% \text { of } \\
\text { GDP })\end{array} \\
2000\end{array}$} \\
\hline & & & & & 1981 & 1991 & \\
\hline $\begin{array}{l}\text { Latin America and } \\
\text { the Caribbean (total) }\end{array}$ & 519752 & 1.7 & 25.0 & 6340 & 1.2 & 3.3 & 43.4 \\
\hline \multicolumn{8}{|l|}{ Countries (by population) } \\
\hline Saint Kitts and Nevis & 41 & -0.3 & 113.4 & 9790 & 5.8 & 4.1 & $128.5^{\mathrm{b}}$ \\
\hline Antigua and Barbuda & 68 & 0.6 & 152.0 & 8890 & 6.1 & 3.3 & $157.7^{\mathrm{b}}$ \\
\hline Dominica & 71 & 0.0 & 97.3 & 4777 & 4.4 & 2.1 & $115.7^{\mathrm{b}}$ \\
\hline Grenada & 94 & 0.3 & 282.9 & 5557 & 4.9 & 3.5 & $99.3^{\mathrm{b}}$ \\
\hline Saint Vincent and the Grenadines & 116 & 0.9 & 290.3 & 4484 & 6.5 & 3.2 & $121.5^{\mathrm{b}}$ \\
\hline Saint Lucia & 154 & 1.3 & 249.2 & 4897 & 6.8 & 2.2 & $133.1^{\mathrm{b}}$ \\
\hline Belize & 241 & 2.6 & 10.5 & 4367 & 4.5 & 4.1 & $101.9^{\mathrm{b}}$ \\
\hline Barbados & 270 & 0.5 & 617.7 & $\ldots$ & 1.1 & 1.4 & $130.4^{\mathrm{b}}$ \\
\hline Suriname & 417 & 0.4 & 2.6 & $\ldots$ & 0.5 & 1.7 & $\ldots$ \\
\hline Guyana & 861 & 1.0 & 4.3 & 3139 & -2.9 & 5.3 & $203.3^{\mathrm{b}}$ \\
\hline Trinidad and Tobago & 1295 & 0.7 & 250.5 & 7208 & -2.6 & 3.0 & $97.7^{\mathrm{b}}$ \\
\hline Jamaica & 2583 & 0.9 & 237.9 & 3344 & 2.2 & 0.1 & $111.7^{\mathrm{b}}$ \\
\hline Panama & 2856 & 1.8 & 37.1 & 4925 & 1.4 & 4.4 & $146.8^{\mathrm{b}}$ \\
\hline Uruguay & 3337 & 0.7 & 18.8 & 8541 & 0.0 & 3.0 & 38.0 \\
\hline Costa Rica & 4023 & 2.8 & 69.1 & 5812 & 2.2 & 5.0 & 94.6 \\
\hline Nicaragua & 5071 & 2.9 & 39.5 & 1896 & -1.5 & 3.3 & 117.8 \\
\hline Paraguay & 5496 & 2.7 & 13.1 & 4312 & 3.0 & 2.2 & 81.2 \\
\hline El Salvador & 6276 & 2.1 & 292.4 & 4008 & -0.4 & 4.6 & 66.3 \\
\hline Honduras & 6485 & 2.9 & 55.0 & 2338 & 2.4 & 3.1 & 101.5 \\
\hline Bolivia & 8329 & 2.4 & 7.3 & 2205 & 0.2 & 3.8 & 41.8 \\
\hline Haiti & 8357 & 1.9 & 277.5 & 1379 & -0.5 & -1.0 & 47.0 \\
\hline Dominican Republic & 8396 & 1.8 & 170.6 & 4337 & 2.4 & 6.3 & 100.9 \\
\hline Cuba & 11199 & 0.5 & 101.1 & $\ldots$ & 3.7 & -1.4 & $\ldots$ \\
\hline Guatemala & 11385 & 2.7 & 99.6 & 3474 & 0.9 & 4.1 & 47.6 \\
\hline Ecuador & 12646 & 2.1 & 44.0 & 3003 & 1.7 & 1.7 & 77.3 \\
\hline Chile & 15211 & 1.5 & 19.8 & 8507 & 3.0 & 6.6 & 60.8 \\
\hline Venezuela & 24170 & 2.2 & 26.3 & 5706 & -0.7 & 2.0 & 51.1 \\
\hline Peru & 25662 & 1.8 & 19.4 & 4180 & -1.2 & 4.2 & 33.2 \\
\hline Argentina & 37032 & 1.3 & 13.2 & 11728 & -0.7 & 4.2 & 23.1 \\
\hline Colombia & 42321 & 1.9 & 39.3 & 5861 & 3.7 & 2.6 & 36.5 \\
\hline Mexico & 98881 & 1.7 & 50.2 & 7450 & 1.9 & 3.5 & 65.0 \\
\hline Brazil & 170693 & 1.4 & 19.6 & 6460 & 1.6 & 2.6 & 23.1 \\
\hline
\end{tabular}

Source: ECLAC and World Bank.

a Includes Aruba, Bahamas, Montserrat, Netherlands Antilles, Puerto Rico and Virgin Islands.

b Visible trade only, 1998.

economic crisis that followed (table 2). In the group of 14 small countries, average per capita income was lower in 2000 than in 1980, so that for them the famous "lost decade" would seem to have lasted 20 years. This indicator fell in eight countries of the group in the period 1981-2000, the worst affected being Haiti and Nicaragua (2.6\% and $1.7 \%$ average annual falls in per capita GDP, respectively). The size factor is just one of many that can influence growth rates, so the workings of other possible causes need to be ascertained if the specific contribution made by a country's size is to be isolated. To this end, an equation has been developed to bring in the various other factors identified by Escaith and Morley (2000) for a panel of 17 countries in the region during the period 1971-1996, excluding the smallest economies. Although the authors' caveats 
TABLE 2

Latin America and the Caribbean: Economic size

and income, 1981-2000

\begin{tabular}{|c|c|c|c|c|}
\hline \multirow[t]{2}{*}{ Countries } & \multirow{2}{*}{$\begin{array}{c}\text { Per capita GDP, } \\
1990^{\mathrm{a}}\end{array}$} & \multicolumn{3}{|c|}{ Average annual per capita GDP growth rate } \\
\hline & & $1981-1990$ & $1991-2000$ & $1981-2000$ \\
\hline Total $^{\mathrm{b}}$ & $\ldots$ & -0.9 & 1.5 & 0.3 \\
\hline Of Latin America ${ }^{\mathrm{b}}$ & $\ldots$ & -0.9 & 1.5 & 0.3 \\
\hline Of the Caribbean ${ }^{\mathrm{b}}$ & $\ldots$ & -0.9 & 1.0 & 0.0 \\
\hline With over 10 million inhabitants ${ }^{c}$ & 7029 & -0.5 & 1.5 & 0.5 \\
\hline With 1 to 10 million inhabitants ${ }^{\mathrm{c}}$ & 4056 & -1.2 & 1.1 & -0.1 \\
\hline With less than 1 million inhabitants ${ }^{\mathrm{c}}$ & 6655 & 3.1 & 2.4 & 2.7 \\
\hline
\end{tabular}

Source: Table 1.

a Dollars at purchasing power parity.

b Average weighted by GDP.

c Simple average.

TABLE 3

Latin America and the Caribbean: Empirical evaluation of growth determinants

\begin{tabular}{lrr}
\hline Variable & Ratio & t-Stat. \\
\hline Constant & 3.237 & 0.96 \\
Average population in 1971-1975 (logarithm) & 0.261 & 2.02 \\
Rural population as proportion of total, average 1971-1975 & -0.033 & -2.50 \\
Per capita income at beginning of each five year subperiod & -0.001 & -7.71 \\
Investment ratio (in relation to GDP) & 0.060 & 1.94 \\
Change in developing country exports to OECD & 0.175 & 8.51 \\
Contribution of primary sectors to GDP & -0.125 & -4.16 \\
Change in export ratio (in relation to GDP) & 0.127 & 2.46 \\
Currency reserves as share of M2 & 0.007 & 1.72 \\
Budget balance (in relation to GDP) & 0.154 & 2.97 \\
Fluctuations in real exchange rate & -0.097 & -4.55 \\
Change in proportion of credit going to private sector & 0.037 & 2.83 \\
Average structural reform index value at beginning of each subperiod & 0.084 & 0.93 \\
Square of this average index value at beginning of each subperiod & -0.001 & -1.19 \\
Change in average reform index during each subperiod & -0.097 & -2.88
\end{tabular}

Source: Author's calculations. Origin and description of data: Escaith and Morley (2000).

a Annual change in per capita GDP.

b Generalized least squares method, weighted and corrected for heteroscedasticity. R-2: 0.83 , using 85 observations (17 countries, five subperiods of five years between 1971 and 1996).

regarding the limitations of this type of analysis have to be taken into account, the results (table 3) tend to show that, other things being equal, ${ }^{2}$ large countries had higher per capita output growth rates.

\footnotetext{
${ }^{2}$ Among the factors, international trade developments and the stability of the domestic macroeconomic framework are the most crucial. Structural reforms have not had a significant global effect, but the lack of progressiveness in their application has clearly had a negative impact.
}

The deviations seen in relation to the predictions of neoclassical theory, which are size-neutral, are due primarily to microeconomic considerations. When a domestic market is small, there are certain economies of scale and complementarities that cannot be achieved, which means higher relative costs and lower competitiveness. These costs, which affect both the public and private sectors, take various forms that can be summed up as below. 


\section{a) Indivisibility, public goods and infrastructure}

Most public services are characterized by indivisibility, which means that for small countries their per capita cost is generally high. Furthermore, as will be seen further on, incomplete or deficient markets often force the State to play an important role in the economy. Furthermore, current public spending as a share of GDP, and the taxation ratio, tend to fall with the size of economies. The need to keep State spending under control also means that the coverage and quality of these services are often less than ideal.

\section{b) Company size and production costs}

Private-sector companies are faced with the same problems, as the small size of the domestic market prevents them from taking advantage of economies of scale. This is particularly true for the non-tradable goods and services sector, whose market is by definition domestic. These disadvantages are less marked in the case of the tradable goods and services sectors, as exports can make up for the small size of the domestic market. Even with access to external markets, however, it is difficult to achieve economies of scale, as even the "large firms" of small countries are small in comparison with their regional competitors and, like many small companies, find it difficult to keep up with the pace of technological progress. Furthermore, they have to incorporate locally produced non-tradable goods and services into their processes at prices that are generally much higher than those paid by their international competitors. In these circumstances, successful participation in regional or international markets must involve a degree of specialization sufficient for critical mass to be achieved. Such specialization tends to be detrimental to complementarity with the rest of the national economy.

\section{c) Market structure}

The smallness of domestic markets, with all this implies for competitiveness, has important consequences for the way they are organized. There are fewer viable firms in sectors exposed to external competition, owing to the high unit costs of production. In protected sectors, a monopolistic structure tends to prevail more or less unchallenged, as the initial costs of breaking into these small markets are high in comparison with the revenue that can be expected.

This monopolistic tendency of domestic markets requires public-sector intervention -be it spontaneous or forced from without by multilateral trade agreements- to correct market failures and regulate competition. Financial constraints and a lack of specialists, however, generally mean that the local public authority is unable to deal with the complex legal and technical implications of this type of regulation. The consequences in terms of lower market efficiency then create a suboptimal situation from the economic point of view.

Both the small size of the labour market and the relative lack of diversification in production activities entail substantial friction and adjustment costs. During growth periods, companies find it hard to take on the skilled labour they need. At times of recession, on the other hand, employment options are few because activities are not very diversified. The unemployment to which this gives rise is difficult to reverse, and shocks tend to be perpetuated. ${ }^{3}$ This last aspect is particularly important if we consider the social costs of any production restructuring that would be required if an economy of this type opened up to free trade.

\section{d) Governance}

Small markets, on the other hand, offer advantages associated with the diseconomies of scale that characterize transaction and supervision costs. In a situation where information about trading partners (customers, suppliers) is readily available, the costs associated with information asymmetries and moral hazard diminish. Reputation, and pressure from society to follow recognized ethical standards, are a partial substitute for the creation of a formal system of regulation and oversight. The small size of the population is also a factor for greater social cohesion and greater citizen participation in the management of public affairs. ${ }^{4}$ These advantages will only bear fruit, however, if the minimum conditions for governance are met, something that is far from being the case in the region..$^{5}$

\footnotetext{
${ }^{3}$ Small economies are also characterized by large-scale labour emigration.

${ }^{4}$ Aristotle saw this cohesion as a source of strength for the State, an idea that was followed up on many occasions by eighteenth century writers (Real de Azúa, 1977).

${ }^{5}$ As is borne out by the civil wars that have ravaged Central America, the ethnic and religious conflicts of the Caribbean and the fractures that have opened up in Ecuadorian society.
} 


\section{Vulnerability}

Over and above differences in growth or development levels, small economies as a group are intrinsically more vulnerable to external shocks than larger ones. In fact, vulnerability is one of the main issues for analyses of the relationships between economic size and welfare in open economies, to such an extent that many small countries have tried - unsuccessfully so far-to introduce this concept as an alternative differentiation criterion in the entitlement clause extending reserved treatment to the least advanced countries in WTO agreements. Three interdependent factors need to be distinguished: geography, demographics and economics.

In combination, the geographical and demographic factors translate into higher population densities that increase pressure on natural resources, threatening fragile ecosystems. Haiti is the most extreme example, but ecological vulnerability is to be found in many of the region's small economies, whose location in tropical regions prone to natural disasters (hurricanes, seismic or volcanic phenomena) compounds the problem yet further. These natural disasters are recurrent and each episode affects a large percentage of the population, or in some cases the whole of the country's territory. In certain Caribbean islands, the damage inflicted on infrastructure and productive activity may exceed GDP. In such situations, the resources available to the national authorities for coping with the emergency and meeting reconstruction costs are woefully inadequate.

As regards the specific issue of social vulnerability, particular attention needs to be paid to the small island developing States of the Caribbean, which are sometimes used as transit or money laundering points by international drug traffickers. Domestic crime linked to the trading and consumption of drugs undermines legal and financial systems and ultimately corrupts all the institutions involved in governance. The social fragility of these islands, and the effects this has on governance, are accentuated yet further by deep-rooted social and cultural fault lines in societies where income is unevenly distributed and ethnic or religious divides are hard to bridge.

The economic dimension of vulnerability in small economies is closely linked to the relative importance of international trade and the lack of export diversification. The coefficient of international trade openness (imports plus exports of goods and services) of the small economies of Latin America and the Caribbean is as much as $85 \%$ of GDP, compared with just 30\% in the region's other economies (ECLAC, 1996). What is more, these exports are largely confined to a small group of products and markets, which makes foreign currency income from external sales highly volatile. Given that the openness coefficient is so high, and that these small economies are extremely dependent on imports to meet the bulk of their domestic demand, fluctuations in export revenue -which is usually not enough to finance imports even in normal times- have a significant impact on domestic activity and the generation of domestic revenue.

The preferential nature of the access that these countries' export products have to the European and United States markets (Lomé agreements, Caribbean Basin Initiative) also makes them dependent on the continuity of the unilateral preferences agreed on. Yet the very spirit of these preferences is being increasingly challenged by the new rules governing international trade since the end of the Uruguay Round.

Specialization in sensitive items such as agricultural, textile and clothing products makes export markets vulnerable to protectionist reactions by the developed economies. Furthermore, the manufactures exported by the countries of Central America and the Caribbean (from maquila industries) have a low capital intensity, which means that subcontracting firms can easily move and are highly sensitive to small changes in comparative production costs.

Nonetheless, this great vulnerability to external trade shocks is compensated for by relative immunity to shocks of a financial nature, which have been the main cause of the latest economic crises in Latin America. Because their financial markets are undeveloped, small economies have not attracted the interest of speculative capital, the scale and volatility of whose flows have given rise to large variations both in relative prices -because of distortions in real exchange rates- and income transfers.

The great trade-related external vulnerability of the region's small economies has led them to adopt macroeconomic policies that are generally more prudent than their neighbours'. Thanks to this relatively conservative approach and to their isolation from speculative capital movements, during the last 20 years the growth rates of the region's small economies have generally fluctuated less than those of larger countries. This result also confirms that the consistency and quality of macroeconomic policy have heavily influenced the long-term growth outcomes seen in the region as a whole over the last 30 years (Escaith and Morley, 2000). 


\section{Economic policy}

Both their size and their external openness give a distinctive character to the economic policies followed by the region's small economies. Rather than being a voluntary choice, this character is due to their having little room for manoeuvre owing to the incompleteness of their domestic markets and an external openness that extends not just to trade, but to the currency markets as well. The small size of local financial markets and the unreliability of domestic saving reinforce the classic "trilemma" of open economies, where the objectives of openness to trade and capital flows, exchange-rate stability and an independent monetary policy cannot all be achieved simultaneously. Under these conditions, it is very difficult for the national authorities, when faced with a recessionary shock, to offset declining domestic demand by expanding domestic financing without running the risk of destabilizing the economy. ${ }^{6}$

Exchange-rate stability is one of the primordial objectives in these small economies that are so open to international trade, and their real exchange rates fluctuate less than those of their larger neighbours. During the period 1989-2000, the standard deviation in exchange-rate indices (normalized to a value of 100 for 1995) was 11 for the small economies, as compared to 21 for the other countries. Most small economies maintained a fixed exchange rate long after the dollar standard agreed on at Bretton Woods came to an end. Costa Rica was the first of the Central American countries to devalue (December 1980), but this was an isolated case, and fixed parities continued to be the rule during the 1980s, although a price was paid for this in the form of multiple exchange rates, non-tariff import restrictions and growing balance-of-payments disequilibria. In the Caribbean, the main economies (the Dominican Republic, Guyana, Haiti, Jamaica and Trinidad and Tobago) also tried to maintain their exchange-rate parities despite alarming domestic and internal disequilibria that finally resulted in hasty devaluations and the application of adjustment programmes.

Nonetheless, the smaller economies of the Caribbean have managed to preserve stable parities (first with the pound, then with the dollar) under normal fixed exchange-rate regimes (Bahamas, Barbados,

\footnotetext{
${ }^{6}$ Nonetheless, these constraints on the ability of macroeconomic policy to react to external shocks do not translate into more volatile growth rates, thanks to the isolation of small economies from speculative capital flows.
}

Belize) or a conversion monetary system administered by the Eastern Caribbean Central Bank, which covers six countries. This strategy has only been possible because of conservative macroeconomic policy and resource transfers, be they direct (development assistance) or through the provisions of preferential trade agreements (specific protocols in the Lomé agreements with the European Union). In South America, for geographical and historical reasons, macroeconomic policy in the small economies during the 1980s was kept close to that followed by their larger neighbours. Exchange rates there were also generally anchored as part of the stabilization efforts of the 1990s.

Fiscal policy likewise has little independence, owing to the precariousness and external dependency of the public finances. Small countries tend to have higher budget deficits than their larger neighbours. In addition, current government revenues come largely from external trade. What is more, in less developed small countries, public-sector investment relies on what is a high level of external aid by regional standards.

Table 4 shows that the countries which are most vulnerable to economic fluctuations, according to the twofold classification of fiscal deficit levels and external dependency, are almost without exception small economies. Thus, macroeconomic policy in these economies remains very reactive, and is more focused than elsewhere on controlling inflation and preserving nominal exchange-rate stability, two objectives that are highly interdependent in economies of this type. Indeed, the facts show that small economies have fewer problems of inflation or devaluation than their larger counterparts in the region (ECLAC, 1996).

These structural constraints on the active and autonomous use of short-term macroeconomic policy, however, do not mean that development policy has to be given up on. Fiscal constraints have not prevented certain small economies -in particular Costa Rica and those of the English-speaking Caribbean- from setting up programmes to invest in human capital (health and education) or applying the fiscal instruments of an aggressive export strategy.

As they are unable to finance costly industrial development assistance programmes, many small economies have introduced productive investment subsidies in the form of exemptions from taxes, both direct and indirect. This has happened particularly in the case of the maquila activities that have been set up in free trade zones, in both Central America and the Caribbean. Some countries have cooperated to build up the infrastructure needed for new activities, as the 
TABLE 4

Latin America and the Caribbean: Budgetary position and dependence on customs revenue

(Averages 1995-1999)

\begin{tabular}{|c|c|c|c|}
\hline $\begin{array}{l}\text { Dependence on } \\
\text { customs revenue: }\end{array}$ & $\begin{array}{l}\text { Surplus or } \\
\text { small deficit }^{\mathrm{a}}\end{array}$ & Moderate deficit ${ }^{b}$ & Large deficit ${ }^{\mathrm{c}}$ \\
\hline Low & Trinidad and Tobago & $\begin{array}{l}\text { El Salvador } \\
\text { Mexico }\end{array}$ & $\begin{array}{l}\text { Bolivia } \\
\text { Brazil } \\
\text { Costa Rica } \\
\text { Uruguay }\end{array}$ \\
\hline Moderate & Chile & $\begin{array}{l}\text { Argentina } \\
\text { Barbados } \\
\text { Guatemala } \\
\text { Panama } \\
\text { Paraguay } \\
\text { Peru }\end{array}$ & $\begin{array}{l}\text { Ecuador } \\
\text { Guyana }\end{array}$ \\
\hline High & Dominican Republic & $\begin{array}{l}\text { Netherlands Antilles } \\
\text { Saint Kitts and Nevis } \\
\text { Saint Lucia } \\
\text { Saint Vincent and the Grenadines } \\
\text { Venezuela }\end{array}$ & $\begin{array}{l}\text { Antigua and Barbuda } \\
\text { Bahamas } \\
\text { Belize } \\
\text { Colombia } \\
\text { Dominica } \\
\text { Grenada } \\
\text { Haiti } \\
\text { Honduras } \\
\text { Nicaragua } \\
\text { Jamaica }\end{array}$ \\
\hline
\end{tabular}

Source: Escaith and Inoue (2001).

a Budget surplus, or deficit of less than 1\% of GDP.

${ }^{b}$ Deficit of between $1 \%$ and $2 \%$ of GDP.

${ }^{c}$ Average deficit in excess of $2 \%$ or highly unstable.

Dominican Republic did as part of its tourism development programme. These initiatives involve major costs, in the form of budgetary spending or uncollected taxes. ${ }^{7}$

These incentive programmes, however, are often necessary to counteract the structural deficiencies (diseconomies of scale, the costs of externalities) characteristic of small economies which, as we have seen, increase production costs and reduce the international competitiveness of local output. The fact

\footnotetext{
${ }^{7}$ In the Dominican Republic, for example, funds to support the development of hotel infrastructure totalled $1.1 \%$ of GDP in 1986, while in Costa Rica revenue that has gone uncollected because of tax exemptions has ranged, depending on the year, from 5\% to $9 \%$ of the total tax take (Escaith and Inoue, 2001).
}

is that they have very often been the key to the success of non-traditional export diversification programmes in the small economies of Central America and the Caribbean (Stallings and Peres, 2000).

The new conditions obtaining in the international market, in particular the rules agreed on within the framework of the Uruguay Round and the international and multilateral agreements that came out of this, are of particular importance for these economies, where the stability of the public finances depends on customs duties that are now being reduced, and where participation in the international economy depends on exports subsidies that are being used less and less. The quality of this participation and the conditions under which it takes place are a source of challenges, but also of opportunities, and these largely determine the economic policy options available. 


\section{II}

\section{Challenges and opportunities}

\section{Globalization, free trade and regional integration}

Orthodox economics has it that small economies are the main beneficiaries of free trade; advocates of globalization argue that the disadvantages deriving from small size can be counteracted by regional integration and the internationalization of production activities. Market opening means that these disadvantages can be overcome as small countries, thanks to their lower structural inertia, would be the best placed to show the flexibility needed to adapt to the conditions of international competition, insofar as their governments adopted the "right" policies. Unfortunately, this optimistic outlook is highly uncertain, and a glance at the theoretical literature on the impact of free trade on economic welfare does not reveal any consensus about its consequences for small economies (Escaith and Pérez, 1999). Rodríguez and Rodrik (1999), after carrying out a critical reading of empirical works on the subject, conclude that the results are not very convincing.

To put it in a more concrete way, many of those running small economies have expressed reservations about their countries' ability to benefit fully from the initiative to create a large Free Trade Area of the Americas (FTAA) as a corollary of the process set in train at the first Summit of the Americas in 1994 to encourage trade integration among all the economies of the continent. They believe that the structural constraints weighing upon small economies such as theirs reduce the potential benefits that their (small) companies could attain through the expansion of their export markets, while the prospect of increased competition from large outside firms makes them fear for their survival.

These doubts should not conceal the net benefits that could be brought by new trade and investment flows, particularly if the opportunity costs of not integrating are taken into account. In fact, the small economies of Central America and the Caribbean do not have many alternatives to integrating into FTAA, the organization that should result from the signing (planned for 2005) of this free trade agreement. If they refused to submit to free trade rules, they would run the risk of being shut out of the markets that currently account for the largest and most dynamic share of their exports. While these countries' exports to the United States now benefit from treatment similar to that granted to Mexico, albeit still with many restrictions, staying out of FTAA would mean that these privileges, which were granted unilaterally, could also be revoked unilaterally. The mere possibility would reduce the advantages they could obtain from the liberalization of trade and, above all, investment movements.

\section{Expected costs and benefits}

From the point of view of a small economy, any assessment of potential costs and benefits should consider the aspects listed below.

\section{a) Trade creation versus trade diversion}

This is a classic case, and it refers to a situation where tariff barriers divert existing trade flows to a fellow member of a free trade zone, to the detriment of external partners that were originally more competitive. In this situation, considering all transaction costs, the creation of a free trade zone among comparable members ought in theory to be beneficial, provided this zone follows the lines that proximity naturally dictates (natural blocs). This proximity helps to minimize diversion effects. Unnatural blocs (i.e., those that bring together unlikely partners or partners separated by high transaction costs) are less likely to contribute to the improvement of their populations' economic welfare (Frankel, Stein and Wei, 1995). This last aspect is potentially of concern for small economies with high transaction costs, whether because they are islands (as in the Caribbean) or, conversely, because they are landlocked (Bolivia and Paraguay). This approach looks even less promising for these small economies -at least in certain theoretical situations- when account is taken of asymmetry among trading partners. In a theoretical frame of reference where competition is imperfect, the advantages obtained from membership of a free trade zone are ultimately linked to the relative size of the partners: large countries generally benefit to the detriment of small ones. 
Nonetheless, as has already been suggested, small economies really have no choice: the threat of trade diversion is a cost for any outside country, which may see its market share collapse if it stays outside a free trade zone. ${ }^{8}$

\section{b) Membership and investment}

Joining a free trade zone not only allows a country to expand its markets (trade creation) but also reduces uncertainty as regards access to those markets. This greater security should translate in turn into a major stimulus for investment in the production of exportable goods and services. This predicted benefit is a poisoned chalice, however, when investments are highly specific to the markets chosen and involve large sunk costs. As we shall see later on, in the long run this situation results in a loss of negotiating power that is not without its costs.

\section{c) Positive externalities}

The macroeconomic authorities of a country that has a history of instability can gain credibility and reduce the perception of country risk by joining forces with more stable partners. Conversely, the contagion effect means that admitting many unstable partners can represent a cost for "well behaved" countries; it is for this reason that a certificate of good macroeconomic behaviour is generally demanded as a prerequisite for membership of a zone of this type.

Other induced effects can be foreseen, such as the consolidation of domestic reform or faster convergence towards internationally recognized quality standards, which should make it possible to enter new markets outside FTAA (Europe, Japan). By the same logic, the obligation to meet stricter environmental protection criteria should open up access to new markets, while also benefiting local populations. These externalities can be substantial for certain countries, when FTAA membership helps consolidate the commitment of the national community to the implementation of structural adjustment programmes and initiatives to restore the country to a sustainable place in the world economy (Finger, Ng and Soloaga, 1998).

\footnotetext{
${ }^{8}$ The situation is not so clear, however, if the entirety of a country's trading relationships are considered. In the case of the Caribbean, particularly, a high percentage of whose trade is with Europe, joining FTAA could result in a large diversion effect vis-à-vis Europe and excessive specialization in relation to the United States. It would thus be preferable for the Caribbean to strike a degree of balance between its two major trading partners.
}

More specifically, belonging to a large free trade zone opens up new opportunities for partnership with neighbouring countries so that large-scale projects can be undertaken jointly, particularly when it comes to the provision of specialized or particularly costly public services (such as higher education and vocational training, infrastructure and market regulation, among others).

\section{d) Dependency}

The balance of costs and benefits becomes even more complicated when account is taken of the political economy and the balance of power. ${ }^{9}$ One element is the ability of each country to manipulate trading conditions to its own advantage by making unilateral tariff changes or introducing non-tariff restrictions, in the event that a trade war breaks out within the free trade zone. As this ability largely depends on respective size, for a large country the potential benefits of open conflict with a small one can easily outweigh the immediate costs. From a dynamic point of view, things become even more difficult for the small economy, as its degree of specialization in its trading links with its larger partner will be higher. Once specialization becomes irreversible, its negotiating power may be reduced to nil (McLaren, 1997). A theoretical figure of this type could be highly appropriate for describing industrialization phenomena based on subcontracting activities, like those that can be seen in certain Caribbean and Central American countries.

The same theoretical models suggest, however, that until the process is completely irreversible, specialization is not a crippling disadvantage if the large country attaches sufficient importance to the expected benefits of free trade (Park, 2000). This theoretical aspect may have interesting implications for small countries as regards negotiating and alliance strategies.

\section{e) Immediate costs and delayed benefits}

From both a theoretical and a practical viewpoint, it is generally recognized that any benefits from free trade are long-term and diffuse, while the costs are visible in the short term and affect some very specific groups. This latter aspect may militate, in particular, against membership of a free trade zone (although, as has already been pointed out, once the zone has

\footnotetext{
${ }^{9}$ For an analysis of the regional integration process in these terms, see particularly Dabène (1998).
} 
been created third-country exporters tend to press for their countries to join in order to limit the effects of diversion). From another point of view, asymmetrical distribution of costs and benefits over time can be a critical factor if the great vulnerability of small economies to external shocks is considered. In extreme cases, if entry does not take place gradually and shocks accumulate in the early years, the small economy can go into crisis and be forced to leave the agreement. It is thus important to give explicit consideration to vulnerability when the preparedness of economies for entering a free trade zone is being considered.

\section{Readiness}

The final balance of the integration costs and benefits referred to will largely depend on how well prepared these economies are to join a free trade zone. Measuring this preparedness is one way of reaching an advance assessment of a given economy's ability to minimize the costs and maximize the benefits. Among the first studies published on the subject was that of Hufbauer and Schott (1994). One of the most complete evaluations of this readiness (ECLAC, 1996) was carried out to support the FTAA negotiations and developed in Escaith and Pérez (1999). The ECLAC methodology looks at 55 indicators, grouped into four categories: eligibility, fundamental variables, policies and risks, these in turn being subdivided by type (macroeconomic, trade, etc.).

Study of these indicators generally bears out the theoretical analyses presented above. Small economies do not differ significantly from large countries as regards their overall eligibility, since their fiscal and balance-of-payments difficulties are offset by greater monetary and exchange-rate stability. Their situation looks worse, however, if non-macroeconomic criteria are considered, as they tend to have fallen behind over time with the application of international labour or environmental protection standards.

As we have seen, the countries of the Caribbean and Central America bring up the rear when it comes to fiscal reform, and are still highly dependent on customs revenue. Their tariffs tend to be even higher and more dispersed than those of their larger neighbours, which implies a certain leaning towards protectionism. Again, the basic indicators generally show that small economies are less advanced, and thus need to apply industrial development and conversion policies in a more sustained way. This situation is often due to their relative development level or the limits placed on industrial diversification by the size of their domestic markets. For example, the agricultural sector generally accounts for a larger share of GDP in small economies, and their exports are less diversified. These indicators show great heterogeneity, however, owing in part to differences in development levels. The countries of Central America (except Costa Rica) and the small countries of South America (except Uruguay) lag behind the English-speaking Caribbean in workforce skills. The latter countries also benefit from better (albeit expensive) transport, energy and telecommunications infrastructure.

Ultimately, it is in their viability and risk levels that small economies are generally most disadvantaged, owing to their greater external vulnerability and a tendency to run larger trade deficits. Yet they do not counteract this vulnerability by building up international reserves. On the contrary, such reserves are generally lower in those countries than in the rest. Again, the governments of small countries depend on customs revenue and official assistance for their public finances, two income sources that are in danger of contracting sharply with the advent of free trade and the policy that industrial countries are adopting of replacing official development assistance with better access to their domestic markets. 


\section{III}

\section{Approaches and prospects}

\section{Economic policy ${ }^{10}$}

As was pointed out earlier, vulnerability is one of the central characteristics of small economies. Reducing it needs to be a priority, all the more so since trade integration, accompanied by greater freedom and stronger guarantees for the movement of capital, can be expected to result in a situation of instability during the transition period. If the experience of the large and medium-sized economies of Latin America is any guide, capital inflows can create situations of excessive domestic demand growth and overvaluation of the exchange rate which are detrimental both to external competitiveness and to the stability of development, and boom-bust cycles can mire the domestic economy in weak average growth.

It is indispensable for countries to build up international reserves during expansionary phases (whilst sterilizing the monetary effect of this accumulation) so that domestic demand can be cushioned over the whole economic cycle. Greater exposure to financial risk, and the trend towards stricter international rules, require better supervision of the banking sector, both for economic reasons and in the interests of public security and foreign policy (particularly in countries that are a target for international drug trafficking).

Countries that are over-dependent on customs revenue to finance public spending need to begin on fiscal reform as soon as possible, with a view to strengthening domestic sources of direct and indirect contributions and thereby preparing for the dismantling of their customs barriers. This reform, together with a new and less procyclical approach to budgetary policy, should also aim to increase domestic saving, one of the weak points of small economies.

A task of the highest importance is to improve the quality of the economic and institutional environment in the region's small economies in the interests of modernizing production, taking into account the preponderance of small businesses in their industrial structure. Since the impact of trade liberalization on

${ }^{10}$ This section draws particularly on the recommendations set forth in ECLAC (2000). small businesses is heterogeneous to say the least, there are both opportunities to create new activities and risks of serial bankruptcies. Existing companies will have to adapt or go under, and it would be a mistake to try to protect them at any price. It is also unlikely, however, that a large group of competitive small companies will come out of nowhere to take advantage of the new opportunities that arise as borders are opened. There needs to be an industrial policy designed to facilitate the emergence of such companies and to stimulate and facilitate strategic adaptation in the case of existing firms.

This can be achieved in a number of ways, for example by amending and simplifying administrative and fiscal rules, providing training assistance and making funds available to help with exporting and technological modernization. Creating free trade zones and promoting clusters of companies is a particularly suitable approach for small economies. Those that have to compensate for the disadvantage of high transaction costs resulting from their geographical isolation (the Caribbean countries) need to capitalize fully on their natural advantages so that they can participate effectively in the regional and international economy. The idea is to concentrate on traditional exports, while increasing their value added and administering them sustainably. This is particularly pertinent to tourism, but it also applies to other natural products (agricultural produce). Investment in human capital, with the focus on creating comparative advantages in certain market niches, is also a real option, as is demonstrated by the transition to high-technology maquila activities that has occurred in Costa Rica. The linguistic specificity and geographical location of the English-speaking islands of the Caribbean also provide scope for diversification into service sectors based on information processing (data processing, trade and finance). Nonetheless, a special effort will have to be made to lower transaction costs as far as possible (development of communications infrastructure, deregulation and competition oversight).

The decade now beginning should give small economies new opportunities to introduce policies that support production development. New technological trends are making it possible to escape to some degree 
from the restrictions imposed by economies of scale (electricity generation, telecommunications), while electronic commerce may open up new markets. Nonetheless, the level of investment in physical and human capital that will be required if these policies are to be applied, and the technical and regulatory demands of the new role being played by the State as intermediary and partner in its relations with the private sector, generally exceed the capabilities of small developing economies.

Consequently, official development assistance is now needed more than ever if these countries are to participate successfully in the new international economy, and the current tendency to reduce this assistance needs to be halted. External assistance is also needed to mitigate the risks entailed by natural disasters, which are recurrent in the region. Besides the direct effects and costs of disasters, these risks mean that insurance premiums for production activities are high. To cope with contingencies, emergency funds need to be created with international assistance; national efforts should focus on delimiting risk areas and carrying out rigorous land use zoning.

\section{Trade negotiations}

Small economies find it harder to gain a hearing in international forums. The few qualified staff they have, whether in their capitals or with wTO in Geneva, are spread among numerous trade meetings that deal with complex, highly specialized subjects, and that are sometimes held simultaneously. It is extremely hard for them to prepare themselves properly to defend their positions, let alone take the initiative.

When it comes to complying with commitments relating to labour legislation or environmental or intellectual property protection entered into at the international or regional level, their capabilities and preparedness are quite low as well. In the specific context of regional integration negotiations, the relative shallowness of domestic industrial networks means that small economies find it harder to comply with minimum thresholds for value added of regional origin. These rules of origin are all the more restrictive in that some of these countries have substantial trade with other regions of the world (those of the Caribbean, for example), which could result in considerable trade diversion once FTAA materializes.

In consequence, it is generally recognized that small economies need to benefit, during a transition phase at least, from specific, differentiated treatment.
This should include a more extended timetable so that the obligations signed up to under trade agreements can be complied with gradually. Flexibility should also apply to thresholds (such as minimum levels of regional value added) or legal and institutional obligations. Again, small economies have to have access to considerable technical assistance, both during and after negotiations. Although these aspects are generally acknowledged, international negotiations have hitherto insisted more on the reciprocity of WTO obligations than on the necessary relationship between trade and development, which incidentally was what led to the failure to resume negotiations in Seattle in late 1999. The current regional negotiations look more promising, at least potentially.

At the second Summit of the Americas (18 and 19 April 1998), and recently at the Fifth Trade Ministerial Meeting (Toronto, 4 November 1999), the 34 Governments involved emphasized the need to ensure that differences in development level and economic size were taken into consideration during the FTAA negotiation process. As yet, however, no concrete steps whatsoever have been taken in this direction and there is complete uncertainty about the form and scope that any such differentiated treatment might have. This situation highlights how hard it is for small economies to make their points of view prevail. This being the case, it is obvious that only if small economies unite around a common position will they be able to tip the balance decisively, but an alliance of this kind is difficult to achieve when the three main groups of small economies -in the Caribbean, Central America and South America- do not always share the same ambitions or the same strategic objectives.

The countries of Central America are looking to strengthen their ties with Mexico and, above all, the United States, but they are going through a difficult stage as an integration group, so that they sometimes negotiate in an uncoordinated fashion. The small economies of South America are positioned around two poles: the North American market, but also Mercosur, especially Brazil. The case of the Caribbean countries is particularly complex. Benefiting in the same way as Central America from privileged access to the United States market by virtue of the Caribbean Basin Initiative (CBI), these countries - particularly Jamaica- have seen in the North American Free Trade Agreement (NAFTA) a threat that they may be squeezed out of that market by products from the Mexican maquila industry.

This concern has been responded to by the recent extension of the preferences granted by the United 
States to the textile and clothing products exported by the CBI countries, among others. The CBI countries, however, are also part of an agreement with the European Union under the old or revised formula of the Lomé agreements, which raises a real problem. ${ }^{11}$ As they were originally understood, the Lomé agreements represented a compromise between aid and trade that took explicit account of the economic asymmetry among those subscribing to them: developing ACP countries, on the one hand, and developed Europe, on the other. In particular, they recognized the importance of giving specific assistance to the least developed island or landlocked countries, so that these could take advantage of the benefits contained in these agreements. Numerous Caribbean countries have depended, and still depend, on these benefits to support much of their economic activity, employment and revenue. As agreements of this type conflict with the new principles governing international trade, however, the ACP countries ended up signing a new agreement with the European Union in Cotonou, after long technical negotiations that culminated in February 2000. The new system translates into potential losses for the ACP countries that could amount to $2 \%$ of exports by value (outside of protocols), calculating from the tariffs in force in 2000. In the case of protocols relating to certain items (plants, agricultural produce and clothing), the loss of preference resulting from application of the Generalized System of Preferences (GSP) is set to exceed 10\% (ACP Group, 1999).

For certain ACP countries in the region, the economic and social consequences of this gradual reduction in the subsidies provided for by the Lomé Convention and the more immediate threats to preferential access for certain strategic products (bananas) are compounded by new obstacles to the development of their offshore financial sector, owing to pressure from countries of the Organisation for Economic Co-operation and Development (OECD) to reduce the tax privileges granted to this sector. But as the maquila example shows, these countries have few ways of attracting the attention of foreign investors and diversifying their activities other than by granting direct subsidies and, most importantly, indirect ones, mainly in the form of tax exemptions. The alternative strategy would be to have WTO classify economic vulnerability -which is a constant in small economies, particularly island ones- as a qualification clause so that the privileges granted to the least advanced countries could be extended to vulnerable economies. This option does not look very likely for the time being.

Excessive trade specialization and asymmetry in negotiating power work against small economies, but the more importance large countries attach to free trade, the less of a disadvantage this is. Consequently, it is in the interests of small trading partners to obtain the support of pressure groups in importing countries (consumer groups, civil society, etc.) to limit the risk of arbitrary protectionist measures, which are often fatal for small exporting companies. Again, the bodies responsible for resolving trade disputes in the region need to be as transparent as possible and work to simple rules that are made known in advance, in order to minimize power plays.

\section{Bibliography}

ACP Group (1999): Conséquences pour les Pays ACP de l'application du système de préférences généralisées, Brussels, 20 April, mimeo.

Dabène, O. (1998): L'intégration régionale dans les Amériques: économie politique de la convergence, Les Etudes du CERI, No. 45, Paris, September.

Damijan, J. (1997): Main economic characteristics of small countries: Some empirical evidence, Development and International Cooperation, vol. XIII, Nos. 24-25, Ljubljana, Yugoslavia, University of Ljubljana, Faculty of Social Sciences, Centre for International Relations.

\footnotetext{
${ }^{11}$ Most of the small economies of Latin America (Andean Group and Central America) benefit from a system of preferential access to the European market comparable to the one that covers the less advanced non-ACP countries, as a way of combating drug trafficking. The impact of this treatment has been marginal, however.
}

De Sierra, G. (coord.) (1994): Los pequeños países de América Latina en la hora neoliberal, Caracas, Nueva Sociedad.

ECLAC (Economic Commission for Latin America and the Caribbean) (1996): El grado de preparación de los países pequeños para participar en el ALCA, Mexico City.

(2000): Equity, Development and Citizenship, LC/G.2071, Santiago, Chile.

Escaith, H. and K. Inoue (2001): Small economies' tariff and subsidy policies in the face of trade liberalization in the Americas, in ECLAC, Thirteenth Regional Seminar on Fiscal Policy. Compendium of documents, Santiago, Chile.

Escaith, H. and S. Morley (2000): The Impact of Structural Reforms on Growth in Latin America and the Caribbean: An Empirical Estimation, Macroeconomía del desarrollo series, No. 1, Santiago, Chile, EClaC.

Escaith, H. and E. Pérez (1999): Los países pequeños y la integración hemisférica, in A. de la Reza and R. Conde (coords.), Nuevas 
dimensiones de la integración. Del TLCAN al regionalismo hemisférico, Mexico City, Plaza y Valdés Editores.

Finger, J.M., F. Ng and I. Soloaga (1998): Trade policies in the Caribbean countries: A look at the positive agenda, Washington, D.C., Caribbean Group for Co-operation on Economic Development (CGCED), June, mimeo.

Frankel, J., E. Stein and S. Wei (1995): Trading blocs and the Americas: The natural, the unnatural and the supernatural, Journal of Development Economics, vol. 47, No. 1, Amsterdam, The Netherlands, Elsevier Science Publishers B.V.

Gutiérrez, M.A. (1996): Is small beautiful for economic integration: The Americas, Journal of World Trade, vol. 30, No. 4, Geneva, Werner Publishing Company Ltd., August.

Hufbauer, G. and J. Schott (1994): Western Hemisphere Economic Integration, Washington, D.C., Institute for International Economics (IIE).

McLaren, J. (1997): Size, sunk costs and Judge Bowker's objection to free trade, The American Economic Review, vol. 87, No. 3, Nashville, Tennessee, American Economic Association.
Park, J. (2000): International trade agreements between countries of asymmetric size, Journal of International Economics, vol. 50, No. 2, pp. 473-495, Amsterdam, The Netherlands, North-Holland Publishing Company.

Real de Azúa, C. (1977): Small nations and the 'constrictive' style of development, CEPAL Review, No. 4, S.77.II.G.5, Santiago, Chile, ECLAC, second half.

Rodriguez, F. and D. Rodrik (1999): Trade Policy and Economic Growth: A Skeptic's Guide to the Cross-National Evidence, Cambridge, Massachusetts, Harvard University, January.

Ros, J. (2000): Development Theory and the Economics of Growth, Ann Arbor, Michigan University Press.

Salvatore, D. (1997): The economic performance of small versus large nations, Development and International Cooperation, vol. XIII, Nos. 24-25, Ljubljana, Yugoslavia, University of Ljubljana, Faculty of Social Sciences, Centre for International Relations.

Stallings, B. and W. Peres (2000): Growth, Employment and Equity: The Impact of the Economic Reforms in Latin America and the Caribbean, Washington, D.C., The Brookings Institution. 